\title{
Reversion of malignant
}

phenotypes of human glioblastoma cells

by $\beta$-elemene through $\beta$-catenin-mediated

regulation of stemness-, differentiation-

and epithelial-to-mesenchymal transition-related molecules

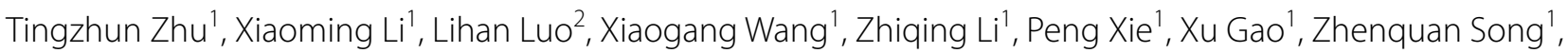 \\ Jingyuan $\mathrm{Su}^{1}$ and Guobiao Liang ${ }^{*}$
}

\begin{abstract}
Background: Glioblastoma is the most common and lethal type of primary brain tumor. $\beta$-Elemene, a natural plant drug extracted from Curcuma wenyujin, has shown strong anti-tumor effects in various tumors with low toxicity. However, the effects of $\beta$-elemene on malignant phenotypes of human glioblastoma cells remain to be elucidated. Here we evaluated the effects of $\beta$-elemene on cell proliferation, survival, stemness, differentiation and the epithelialto-mesenchymal transition (EMT) in vitro and in vivo, and investigated the mechanisms underlying these effects.

Methods: Human primary and U87 glioblastoma cells were treated with $\beta$-elemene, cell viability was measured using a cell counting kit-8 assay, and treated cells were evaluated by flow cytometry. Western blot analysis was carried out to determine the expression levels of stemness markers, differentiation-related molecules and EMT-related effectors. Transwell assays were performed to further determine EMT of glioblastoma cells. To evaluate the effect of $\beta$-elemene on glioblastoma in vivo, we subcutaneously injected glioblastoma cells into the flank of nude mice and then intraperitoneally injected $\mathrm{NaCl}$ or $\beta$-elemene. The tumor xenograft volumes were measured every 3 days and the expression of stemness-, differentiation- and EMT-related effectors was determined by Western blot assays in xenografts.

Results: $\beta$-Elemene inhibited proliferation, promoted apoptosis, impaired invasiveness in glioblastoma cells and suppressed the growth of animal xenografts. The expression levels of the stemness markers CD133 and ATP-binding cassette subfamily $\mathrm{G}$ member 2 as well as the mesenchymal markers $\mathrm{N}$-cadherin and $\beta$-catenin were significantly downregulated, whereas the expression levels of the differentiation-related effectors glial fibrillary acidic protein, Notch1, and sonic hedgehog as well as the epithelial marker E-cadherin were upregulated by $\beta$-elemene in vitro and in vivo. Interestingly, the expression of vimentin was increased by $\beta$-elemene in vitro; this result was opposite that for the in vivo procedure. Inhibiting $\beta$-catenin enhanced the anti-proliferative, EMT-inhibitory and specific marker expression-regulatory effects of $\beta$-elemene.
\end{abstract}

\footnotetext{
*Correspondence: syjqzyyliangguobiao@yahoo.com

1 Department of Neurosurgery, General Hospital of Shenyang Military

Area Command, No. 83, Wenhua Road, Shenhe District, Shenyang 110840,

China

Full list of author information is available at the end of the article
} 
Conclusions: $\beta$-Elemene reversed malignant phenotypes of human glioblastoma cells through $\beta$-catenin-involved regulation of stemness-, differentiation- and EMT-related molecules. $\beta$-Elemene represents a potentially valuable agent for glioblastoma therapy.

Keywords: $\beta$-Elemene, Glioblastoma, Malignant phenotype, $\beta$-Catenin

\section{Background}

Glioblastoma is the most common and lethal type of primary brain tumor, accounting for approximately $52 \%$ of primary intracranial tumors. Malignant phenotypes, including rapid proliferation, anti-apoptosis, resistance to radiation and chemotherapy and the tendency to peripherally invade, result in the reduction of therapeutic efficacy [1-4].

Elemene, an effective anti-tumor medicine, is extracted from Curcuma wenyujin as an essential oil mixture of $\beta$-, $\gamma$ - and $\delta$-elemene [5]. $\beta$-Elemene (PubChem CID: 10583), the major active anticancer component in the elemene mixture, displays high anti-proliferative activity and induces apoptosis in various tumors, such as glioma and breast carcinoma $[6,7]$. We previously found that $\beta$-elemene arrested C6 and U87 glioblastoma cells in the G0/G1 phase of the cell cycle and inhibited cell proliferation by regulating the glia maturation factor $\beta /$ mitogenactivated protein kinase kinase $3 / 6 /$ p38 and extracellular signal-regulated kinase $1 / 2 / \mathrm{B}$ cell lymphoma 2 /survivin pathways [7-10]. $\beta$-Elemene also inhibited cell proliferation and promoted differentiation of glioblastoma stem cells (GSCs) in vitro and in vivo [11]. However, the antiglioblastoma effects of $\beta$-elemene and the mechanisms underlying these activities remain to be elucidated.

GSCs are a small population (1-10\%) of glioblastoma cells with some neural stem cells (NSCs) properties. GSCs are more difficult to kill than the differentiated population of glioblastoma cells owing to stronger phenotypes in promoting anti-apoptosis, invasion and resistance to chemoradiotherapy [11, 12]. Promoting GSC differentiation is a crucial therapeutic strategy in treating glioblastoma. Human CD133, a $120 \mathrm{kDa}$ cell surface protein, has been accepted as the standard marker for the identification of GSCs, although CD133 may not be exclusively expressed on these cells or represent the ideal marker of this cell type [13-15]. ATP-binding cassette subfamily G member 2 (ABCG2), a chemotherapy resistance-related molecule, is strongly expressed in NSCs and tumor stem cells (TSCs) but is commonly inactive in further matured cells. Therefore, ABCG2 is considered to be an alternative GSC marker [16-20]. The expression of the differentiation marker glial fibrillary acidic protein (GFAP) is low in NSCs and GSCs and gradually increases during the cellular differentiation process. Additionally, Notch1 and Sonic hedgehog (SHH) are also closely associated with the differentiation of various tumor cells [21-23].

The epithelial-to-mesenchymal transition (EMT) is a unique invasion process that is typically accompanied by a decrease in the expression of the epithelial marker E-cadherin and an increase in the expression of the mesenchymal markers vimentin, $\mathrm{N}$-cadherin and $\beta$-catenin. Inhibiting EMT would impair tumor cell invasiveness and improve patient prognosis [24, 25].

As the key regulator of both normal development and tumorigenesis, Wnt $/ \beta$-catenin signaling plays a crucial role in the progression of human glioma. Accumulating evidence suggests that a complex crosstalk exists between the $\beta$-catenin pathway and various stemness-, differentiation- and EMT-related effectors [26-28].

In this study, we determined the effect of $\beta$-elemene on various malignant phenotypes in primary and U87 glioblastoma cells in vitro and in vivo.

\section{Methods}

\section{Reagents and antibodies}

$\beta$-Elemene (98 \% purity) was obtained from Jingang Pharmaceutical Co. (Dalian, China). Antibodies against CD133, ABCG2 and GFAP that were used for Western blot and immunohistochemistry analyses were purchased from Boster Co., Ltd. (Wuhan, China). GAPDH antibody was obtained from Santa Cruz Biotechnology, Inc. (Santa Cruz, CA, USA), and the antibodies against Notch1, $\mathrm{SHH}, \beta$-catenin, vimentin, $\mathrm{E}$-cadherin and $\mathrm{N}$-cadherin were purchased from Cell Signaling Technology, Inc. (Danvers, MA, USA). XAV939 (PubChem CID: 2726824) was purchased from Selleck Chemicals (Houston, TX, USA). Accutase Cell Dissociation Reagent was obtained from Invitrogen Corp. (Carlsbad, CA, USA). The cell counting kit-8 (CCK-8) was obtained from Dojindo Molecular Technologies, Inc. (Kumamoto, Japan). The Annexin $V$-FITC/propidium iodide (PI) apoptosis detection kit was purchased from BD Biosciences (Bedford, MA, USA). Nude mice were provided by the Experimental Animal Center of the Academy of Military Medical Sciences.

\section{Cell culture}

The human U87 glioblastoma cell line was purchased from the Shanghai Cell Bank of the Chinese Academy of Sciences. The primary and U87 glioblastoma cells 
were maintained in Dulbecco's modified eagle's medium (DMEM; Hyclone Laboratories, Logan, UT, USA) supplemented with $10 \%$ fetal calf serum (Invitrogen), $50 \mathrm{IU} / \mathrm{ml}$ penicillin (Invitrogen) and $50 \mathrm{mg} / \mathrm{ml}$ streptomycin (Invitrogen) and cultured at $37{ }^{\circ} \mathrm{C}$ in a humidified atmosphere containing $5 \% \mathrm{CO}_{2}$.

\section{Tumor specimens and primary cell cultures}

Brain tumors located in different regions of the brain often show different symptoms, prognosis and even biological behaviors. To enhance the compatibility of our results, this study included two cases (G1: male, 46 years old, WHO grade III; G2: male, 39 years old, WHO grade IV) with glioblastoma in frontal lobes who received surgical resection of glioblastoma in the Department of Neurosurgery of the General Hospital of Shenyang Military Area Command. Each patient's head-enhanced magnetic resonance imaging (MRI) images are shown in Fig. 1. This study was approved by the Ethics Committee of the General Hospital of Shenyang Military Area Command and abided by the Declaration of Helsinki; informed consent was obtained from all study participants. The G1 and G2 tumor samples were stored in sterile serum-free DMEM and processed within $0.5 \mathrm{~h}$ after resection. The tissues were cut into $1 \mathrm{~mm}^{2}$ pieces, washed with phosphate-buffered saline (PBS) and digested using $0.25 \%$ trypsin at $37{ }^{\circ} \mathrm{C}$ for $15 \mathrm{~min}$. The G1 and G2 primary glioblastoma cells were cultured in serum-containing DMEM after filtering through a $70 \mu \mathrm{m}$ strainer (BD Biosciences).

\section{Immunohistochemistry}

Paraffin sections of the glioblastoma tissues were obtained and deparaffinized. Antigen retrieval was performed using citrate buffer, pH 6.0 (Invitrogen). Non-specific sites were blocked by incubating the sections in $5 \%$ bovine serum albumin (BSA) in a humidified chamber for $1 \mathrm{~h}$ at room temperature. The samples were incubated in $0.3 \% \mathrm{H}_{2} \mathrm{O}_{2}$ for $15 \mathrm{~min}$ to block endogenous peroxidase activity and then labeled with different primary antibodies (1:100 for CD133, ABCG2 and GFAP) for $1 \mathrm{~h}$ at room temperature. We used the Vectastain ABC kit (Vector Labs., Burlingame, CA, USA) and diaminobenzidine (Changdao Biotech, Shanghai, China) as a chromogen. Nuclear counterstaining of the sections was performed using hematoxylin. In all tissues, one section was stained without the primary antibody in parallel as a negative control.

\section{CCK-8 assay}

Cell viability was evaluated using the CCK- 8 assay in cells cultured in a 96-well plate in the exponential growth phase. Trypan blue staining confirmed $>80 \%$ cell viability, and the cells were treated according to the study design. Then, $10 \mu \mathrm{l}$ of CCK- 8 was added to each well and the mixture was incubated for $4 \mathrm{~h}$ at $37^{\circ} \mathrm{C}$. The optical density of each well was measured at $450 \mathrm{~nm}$ using a spectrophotometric microplate reader (Bio-Tek Instruments Inc., Winooski, VT, USA). Five replicate wells were used for each condition.

\section{Cell proliferation assay}

Cells $\left(4 \times 10^{5}\right.$ cells per well) were grown in six-well plates overnight and then treated with various concentrations of $\beta$-elemene for $24 \mathrm{~h}$. Trypan blue staining confirmed $>80 \%$ cell viability, and cell numbers were determined by cell counting (Beckman Coulter, Miami, FL, USA).
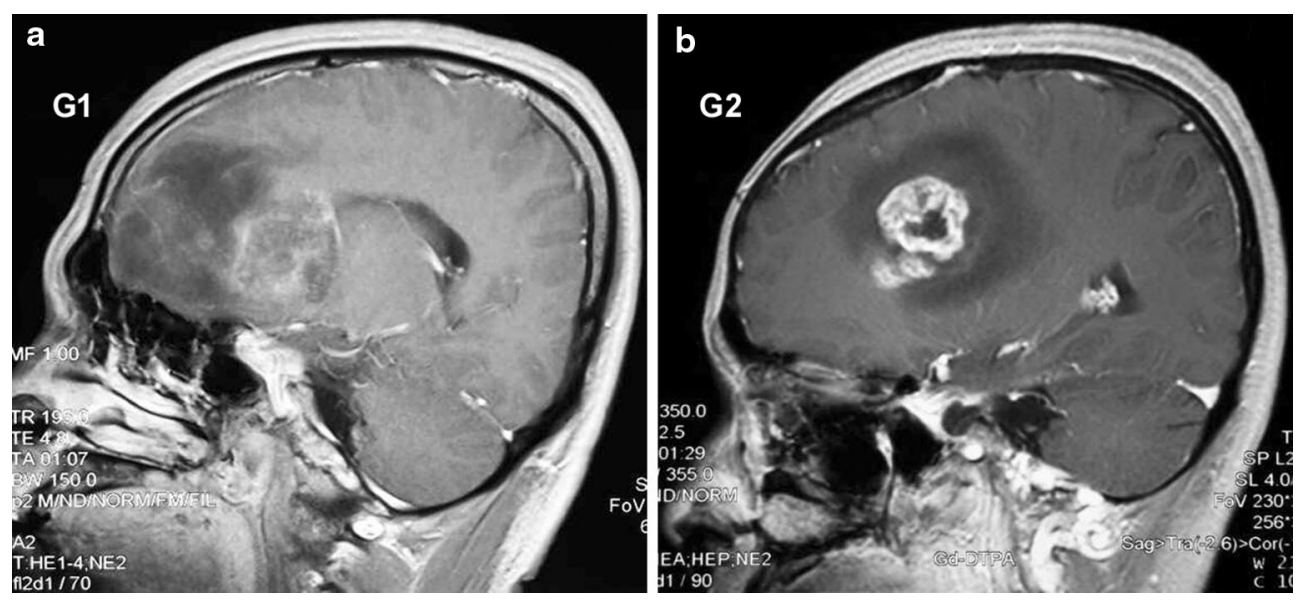

Fig. 1 Head-enhanced MRI images for patients G1 and G2. a The head-enhanced MRI image of patient G1, who exhibited a glioblastoma in the right frontal lobe. b The head-enhanced MRI image of patient G2, who exhibited a glioblastoma in the left frontal lobe 


\section{Detection of cell death using flow cytometry}

Primary and U87 glioblastoma cells $\left(6 \times 10^{5}\right.$ cells $)$ were seeded on $6 \mathrm{~cm}$ diameter culture dishes, incubated for $24 \mathrm{~h}$, and then treated with $\beta$-elemene at various concentrations for $24 \mathrm{~h}$. Both live and dead cells (including both the adherent cells and the cells suspended in the medium) were collected, washed with PBS, and then resuspended in binding buffer (BD Biosciences), to which Annexin V-FITC and PI were added. Flow cytometry assay was performed to evaluate apoptosis. All in vitro experiments were conducted in triplicate.

\section{Western blot}

Cells were lysed using RIPA buffer [50 mM Tris-HCl (pH 7.4), $1.0 \%$ NP-40, $0.25 \%$ Na-deoxycholate, $1 \mathrm{mM}$ EDTA, $150 \mathrm{mM} \mathrm{NaCl}, 1 \mathrm{mM}$ aprotinin, $1 \mathrm{mg} / \mathrm{ml}$ PMSF, $1 \mu \mathrm{g} / \mathrm{ml}$ pepstatin and $1 \mu \mathrm{g} / \mathrm{ml}$ leupeptin]. The total protein concentrations in the cellular extracts were measured using the BCA assay kit from Keygen Biotech. Co., Ltd. (Nanjing, China). After separation via $10 \%$ sodium dodecyl sulfate-polyacrylamide gel electrophoresis, the proteins were transferred to nitrocellulose filter membranes (Bio-Rad, Hercules, CA, USA). The membranes were blocked using $5 \%$ BSA in Trisbuffered saline containing Tween 20 at $4{ }^{\circ} \mathrm{C}$ overnight. The membranes were probed using various primary antibodies at $4{ }^{\circ} \mathrm{C}$ overnight, followed by incubation in horseradish peroxidase-conjugated secondary antibodies at $37^{\circ} \mathrm{C}$ for $1.5 \mathrm{~h}$. The membranes were exposed to an ECL system (Amersham Biosciences, Uppsala, Sweden), and chemiluminescence was detected by exposing the membranes to $x$-ray film (Fujifilm Co., Ltd., Tokyo, Japan). The results were digitized using Image Quant 5.2 software (Amersham), and the gray values of the bands were semi-quantitatively evaluated using GelPro Analyzer 4.0 software (Media Cybernetics, Rockville, MD, USA). The gray values were normalized to those of GAPDH.

\section{In vitro invasion assays}

Cell invasion assays were performed in 24-well plates equipped with $8 \mathrm{~mm}$ pore size chamber inserts (Corning, New York, NY, USA). Cells were diluted in serum-free culture medium and placed in upper wells $\left(1 \times 10^{5}\right.$ cells per well) that were previously coated with Matrigel (BD Biosciences). Cells were suspended in $200 \mu \mathrm{l}$ of serumfree DMEM (supplemented with $\beta$-elemene, dimethyl sulfoxide (DMSO) or $10 \mu \mathrm{M}$ XAV939) upon seeding on the upper chamber. In the lower chamber, $500 \mu \mathrm{l}$ of DMEM supplemented with $20 \%$ fetal bovine serum was added. After incubation for $12 \mathrm{~h}$ at $37{ }^{\circ} \mathrm{C}$, the membrane inserts were removed from the plate and the non-invading cells were removed from the upper surface of the membrane. The cells that moved to the bottom surface of the upper chamber were fixed using $100 \%$ methanol for $15 \mathrm{~min}$ and stained with $0.1 \%$ crystal violet for $30 \mathrm{~min}$. Cells were imaged and counted in 16 fields using an inverted microscope (ECLIPSE TE2000-U, Nikon, Tokyo, Japan). The assays were conducted in triplicate.

\section{Transplantation of glioblastoma cells into nude mice and treatment of the animals}

A total of $1 \times 10^{5}$ glioblastoma cells (suspended in $0.2 \mathrm{ml}$ DMEM) were subcutaneously injected into the right shoulder region of each 4-week-old female nude mouse. Various drugs were intraperitoneally injected beginning on day 6 after transplantation. The tumor volumes were measured every 3 days and were calculated according to the equation $\mathrm{V}=1 / 2 \times$ largest diameter $\times$ smallest diameter $^{2}$ [8]. The tumors were weighed on day 21 after transplantation. All experimental procedures involving animals were also approved by the Institutional Animal Care and Use Committee of the General Hospital of Shenyang Military Area Command. All efforts were made to minimize animal suffering and discomfort and to reduce the number of animals used.

\section{Statistical analysis}

The values were reported as the mean \pm standard deviation (SD) of at least three independent experiments. The data were analyzed using Student's t test for comparisons of two groups or using a one-way analysis of variance followed by Tukey's post hoc test for multiple comparisons. Statistical significance was accepted at the level of $p<0.05$ between different groups, and $p<0.01$ was considered to be highly significant. The statistical analyses were performed using SPSS software version 16.0 (SPSS, Inc., Chicago, IL, USA).

\section{Results}

\section{$\beta$-Elemene inhibited the proliferation of primary and U87} glioblastoma cells

To evaluate the anti-tumor effect of $\beta$-elemene on glioblastoma cells, G1, G2 and U87 cells were treated with $\beta$-elemene at 0 (untreated), $50,100,150$ or $200 \mu \mathrm{g} / \mathrm{ml}$ for $24 \mathrm{~h}$. G1 and G2 cells were fusiform or polygonal, displaying clear cellular atypia and pathological nuclear fission. Multinucleated or giant tumor cells were occasionally detected among the G1 and G2 cells. G1, G2 and U87 cells treated with $\beta$-elemene gradually shrank and a small proportion of the cells died and floated in the medium (Fig. 2a). CCK-8 assays showed that both viability and number of cells treated with $\beta$-elemene decreased in a dose-dependent manner (Fig. 2b, c). These results indicated that $\beta$-elemene inhibited the proliferation of human glioblastoma cells. 


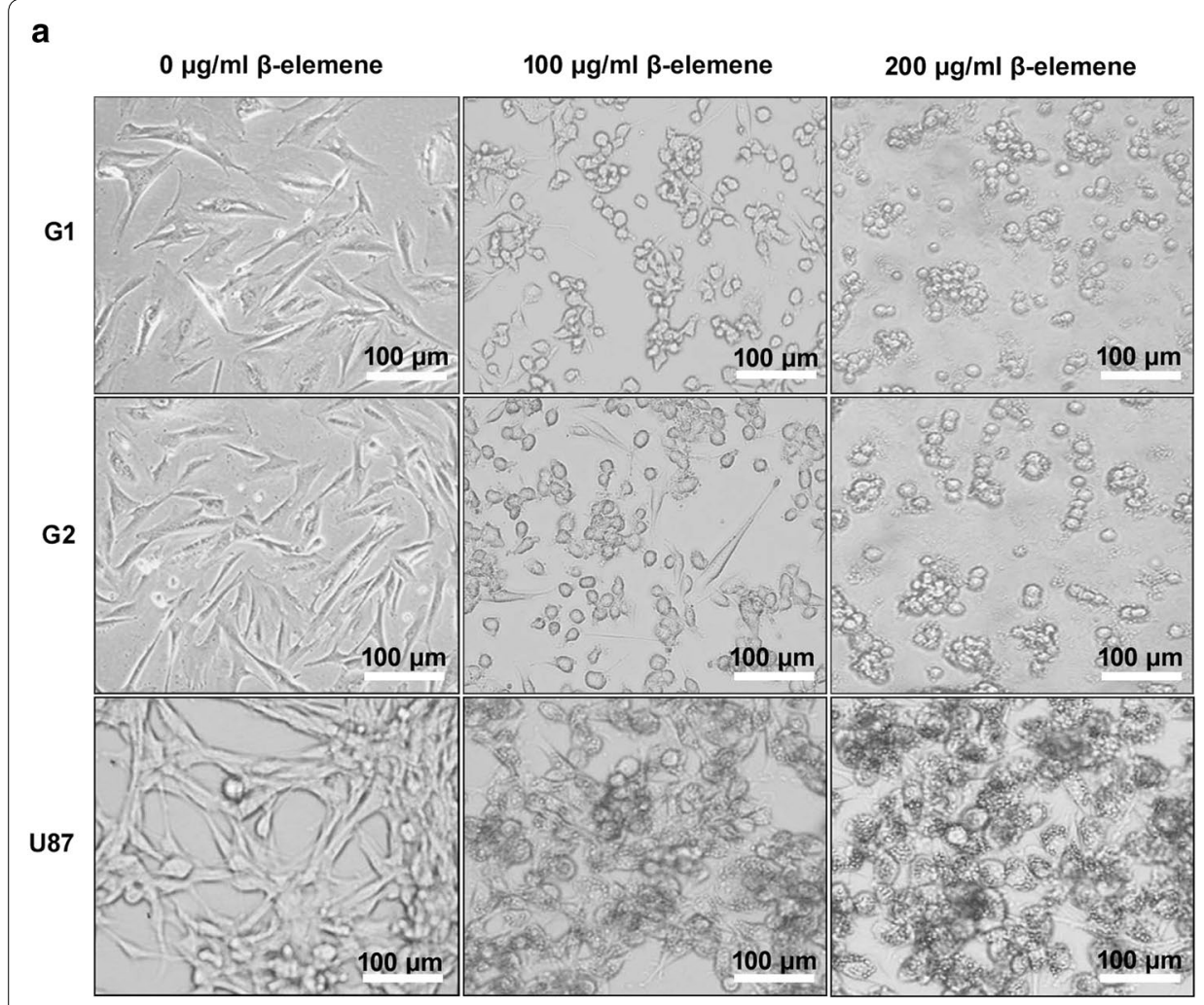

b
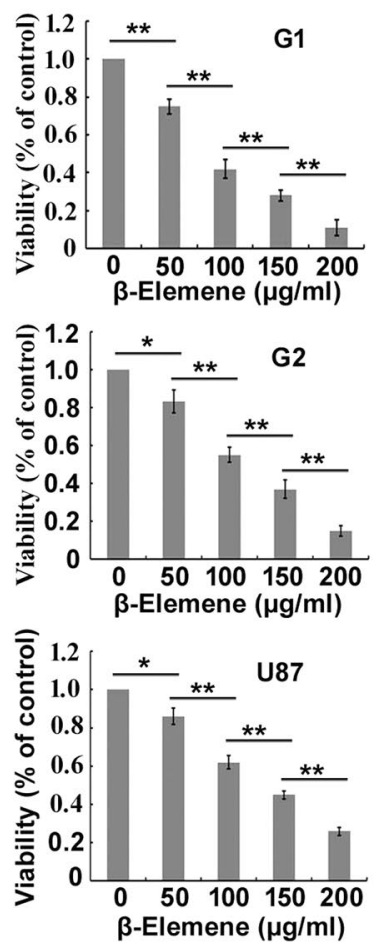

C

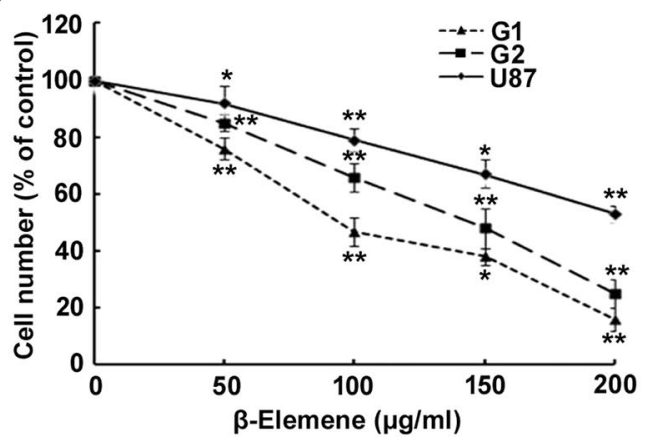

d<smiles>C=CC1(C)CCC(C(=C)C)CC1C(=C)C</smiles>

$\beta$-Elemene

Fig. $2 \beta$-Elemene inhibited the proliferation and viability of glioblastoma cells. a G1 and G2 cells were fusiform or polygonal, displaying clear cellular atypia and pathological nuclear fission. Upon treatment with $\beta$-elemene, the glioblastoma cells gradually shrank, and a small proportion of the cells died and floated in the medium. b Cell viability was clearly inhibited by $\beta$-elemene in a concentration-dependent manner. c Cell numbers were impaired by $\beta$-elemene in a concentration-dependent manner. $\mathbf{d}$ The molecular structure of $\beta$-elemene. The values are presented as the mean \pm SD $\left({ }^{*} p<0.05,{ }^{* *} p<0.01\right)$. Scale bar $100 \mu \mathrm{m}$

\section{$\beta$-Elemene induced glioblastoma cell apoptosis}

To evaluate the effect of $\beta$-elemene on glioblastoma cell apoptosis, G1, G2 and U87 cells were treated with $\beta$-elemene at 0 (untreated), 100 or $200 \mu \mathrm{g} / \mathrm{ml}$ for $24 \mathrm{~h}$. Both live and dead cells (including both the adherent cells and the cells suspended in the medium) were collected and flow cytometry was performed using an Annexin V/ PI detection kit. More than $90 \%$ of the untreated G1, G2 and U87 cells were viable. Figure 3 shows flow cytometry data from treated cells; viable cells are located in the lower left quadrant, cells in early apoptosis are located in the lower right quadrant, cells in late apoptosis stage or that are already dead are located in the top right quadrant and necrotic cells are located in the top left quadrant [29]. As the $\beta$-elemene dose increased, the proportions of apoptotic cells were dramatically increased. These results indicated that $\beta$-elemene induced glioblastoma cell apoptosis. 

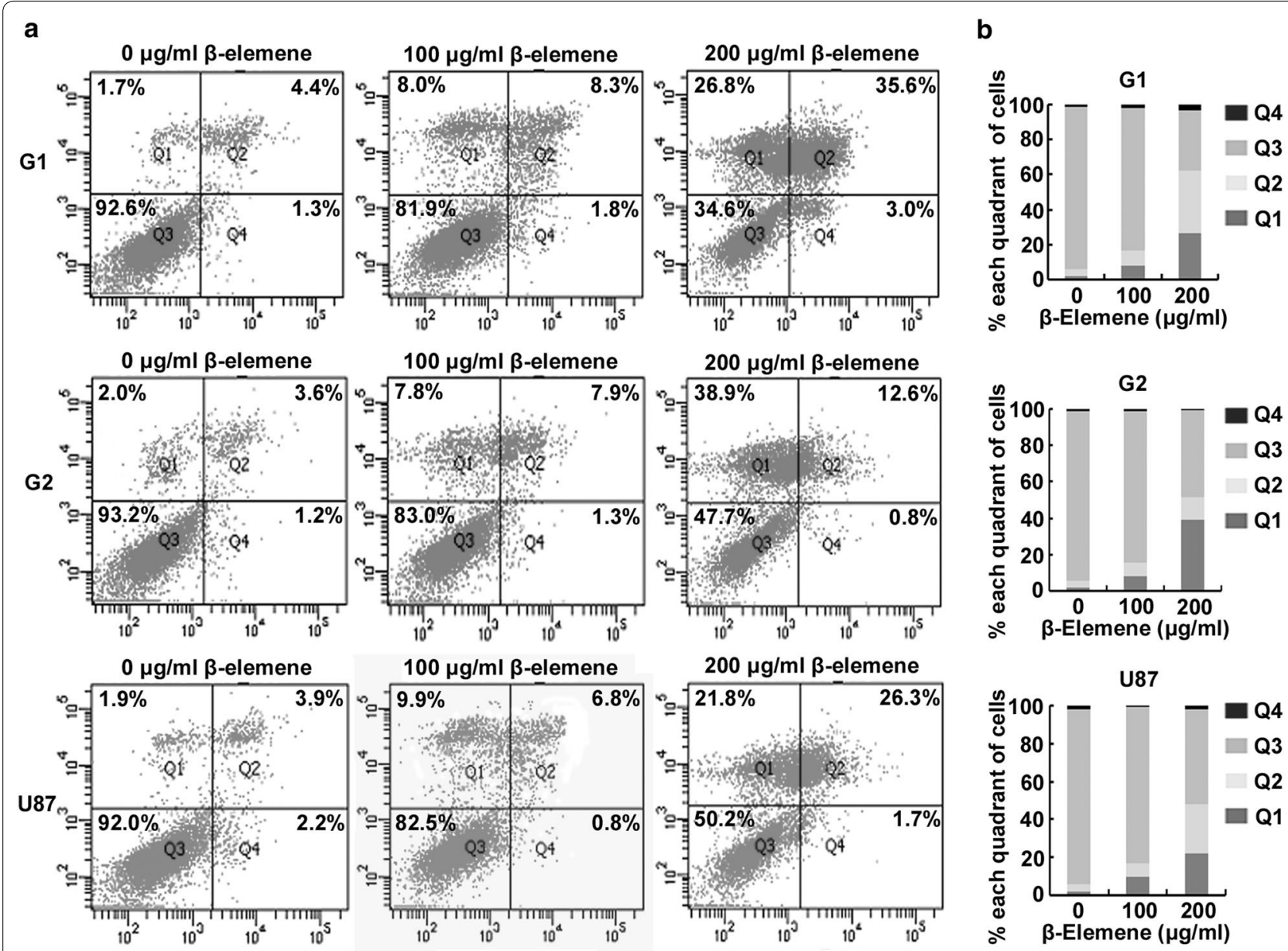

Fig. 3 Induction of apoptosis in glioblastoma cells after incubation in $\beta$-elemene for $24 \mathrm{~h}$. a Glioblastoma cells were treated with $\beta$-elemene for $24 \mathrm{~h}$. Flow cytometry was performed using an Annexin V/PI detection kit. Upon treatment with $\beta$-elemene, the proportions of apoptotic cells clearly increased in a dose-dependent manner. Viable cells are located in the lower left quadrant, cells in the early apoptosis stage are located in the lower right quadrant, cells in the late apoptosis stage or already dead are located in the top right quadrant and necrotic cells are located in the top left quadrant. $\mathbf{b}$ The results in (a) are illustrated graphically. These results are representative of three independent experiments

$\beta$-Elemene regulation of the expression of stemnessand differentiation-related effectors in glioblastoma cells

We next performed immunohistochemical analysis to investigate the expression levels of stemness (CD133, ABCG2) and differentiation-related markers (GFAP) in human glioblastoma tissues. Both CD133- and ABCG2positive cells were sparsely distributed throughout the glioblastoma tissues and both CD133 and ABCG2 were localized to both the cytoplasm and cytomembrane. The expression of GFAP was detected in both the G1 and G2 tissues and was higher in the G1 tissue than in the G2 tissue (Fig. 4a).

We next performed Western blot analysis to evaluate the expression levels of the stemness markers CD133 and ABCG2 and differentiation-related molecules GFAP, Notch2 and SHH in G1, G2 and U87 cells treated with $0,50,100$ or $200 \mu \mathrm{g} / \mathrm{ml} \beta$-elemene for $24 \mathrm{~h}$. The expression levels of CD133 and ABCG2 were significantly downregulated by $\beta$-elemene whereas the expression levels of GFAP, Notch1 and SHH were upregulated in a dose-dependent manner (Fig. 4b, c). Together these results suggested that $\beta$-elemene inhibited the expression of stemness markers and increased the expression of differentiation-related effectors in glioblastoma cells in vitro.

\section{$\beta$-Elemene regulation of the expression of EMT-related effectors in glioblastoma cells in vitro}

To evaluate the effect of $\beta$-elemene on the expression of EMT-related effectors, G1, G2 and U87 cells were treated with $0,50,100$ or $200 \mu \mathrm{g} / \mathrm{ml} \beta$-elemene for $24 \mathrm{~h}$ and Western blot analysis was performed to evaluate 


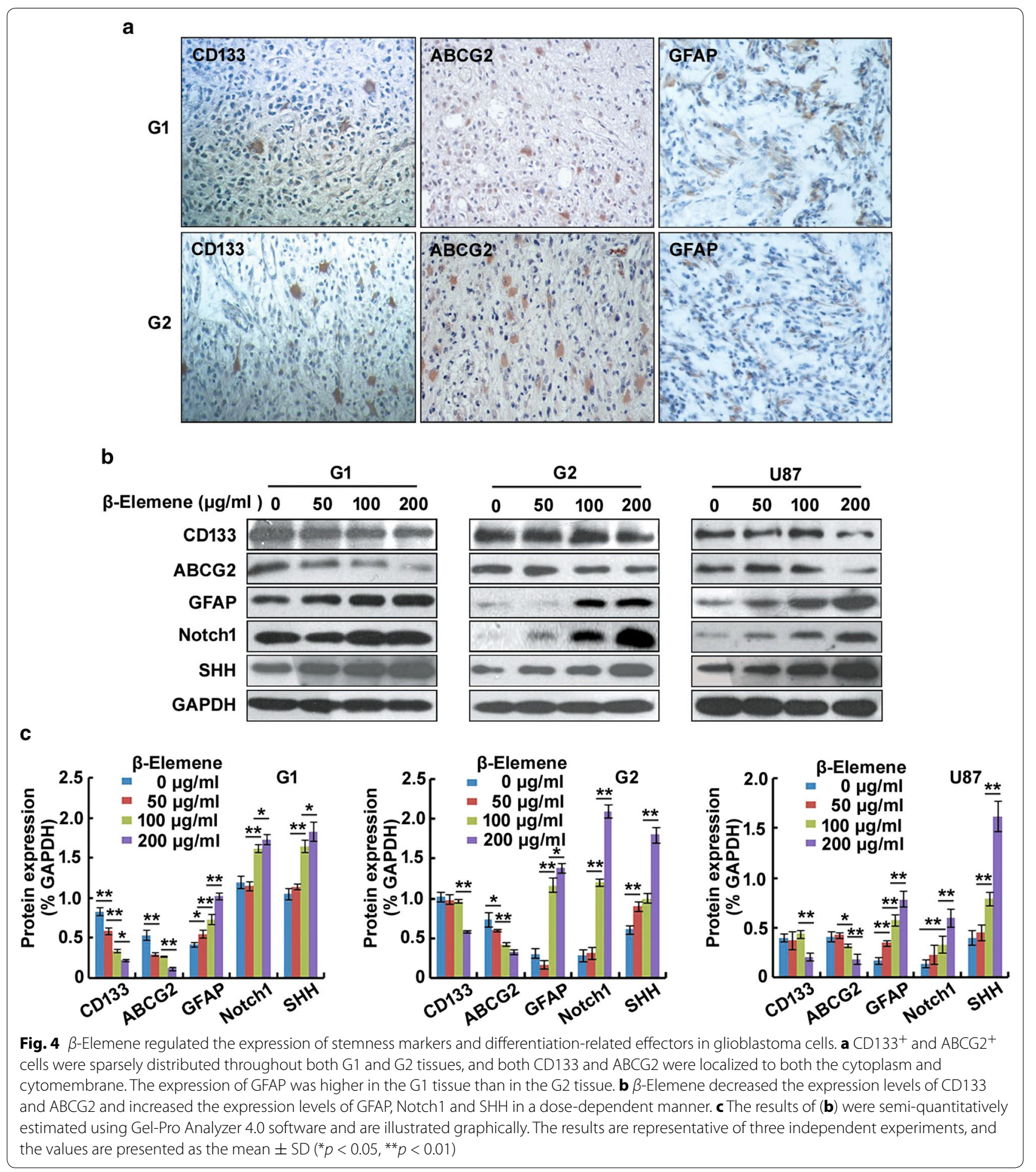

vimentin, E-cadherin, $\mathrm{N}$-cadherin and $\beta$-catenin expression. The results revealed that $\beta$-elemene increased the expression levels of vimentin and E-cadherin and decreased the expression levels of $\mathrm{N}$-cadherin and $\beta$-catenin (Fig. 5).
$\beta$-Elemene decreased the invasiveness of glioblastoma cells by suppressing $\beta$-catenin expression

Transwell assays were performed to further determine the effect of $\beta$-elemene on EMT in glioblastoma cells. To evaluate the role of the $\beta$-catenin signaling pathway, 


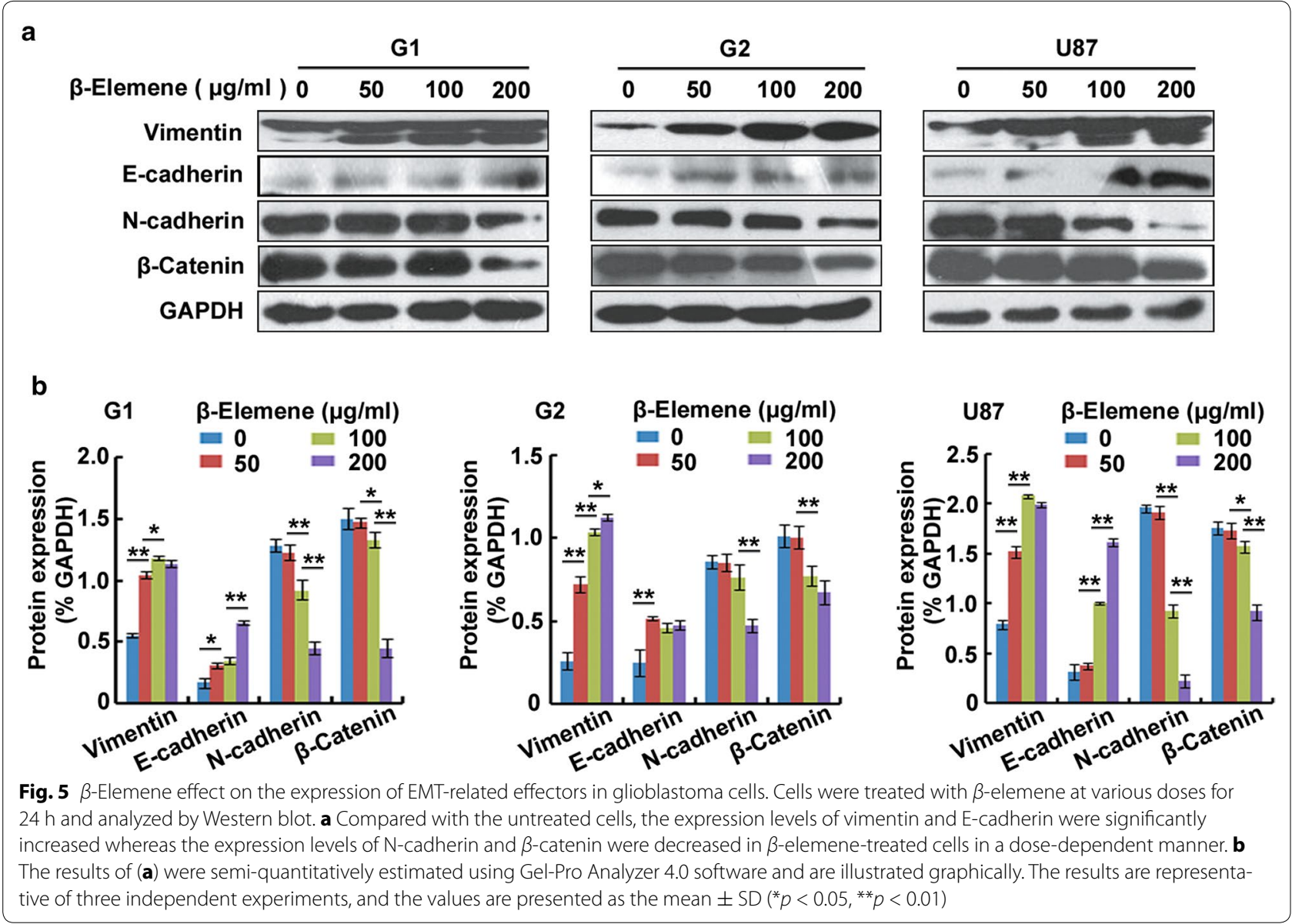

we also used the $\beta$-catenin inhibitor XAV939. Treatment conditions of $50 \mu \mathrm{g} / \mathrm{ml} \beta$-elemene for $12 \mathrm{~h}$ were selected because this treatment did not markedly decrease the number of cells. We examined three treatment groups: DMSO, $50 \mu \mathrm{g} / \mathrm{ml} \beta$-elemene + DMSO, and $50 \mu \mathrm{g} / \mathrm{ml} \beta$-elemene $+10 \mu \mathrm{M}$ XAV939 (dissolved in DMSO) for $12 \mathrm{~h}$. We observed decreased invasion of G1, G2 or U87 cells in the $\beta$-elemene + DMSO group compared with the DMSO alone control group. Notably, the $\beta$-elemene + XAV939 groups showed further decreased invasion compared with $\beta$-elemene + DMSO group (Fig. 6). Together these results indicated that $\beta$-elemene decreased the invasiveness of glioblastoma cells and that this effect was amplified by the $\beta$-catenin inhibitor XAV939.

\section{Anti-glioblastoma effects of $\beta$-elemene were enhanced by inhibiting $\beta$-catenin expression}

To evaluate the role of the $\beta$-catenin signaling pathway in the anti-glioblastoma effects of $\beta$-elemene, we treated glioblastoma cells with $50 \mu \mathrm{g} / \mathrm{ml} \beta$-elemene in the presence or absence of the $\beta$-catenin inhibitor XAV939 for
$24 \mathrm{~h}$. CCK- 8 assay results revealed that treatment with 5 or $10 \mu \mathrm{M}$ XAV939 markedly augmented the anti-proliferative effect of $\beta$-elemene (Fig. 7a). Western blot analysis showed that XAV939 at $10 \mu \mathrm{M}$ clearly reduced the expression of $\beta$-catenin and upregulated the expression levels of E-cadherin, GFAP, Notch1 and vimentin but did not alter the expression levels of CD133 or N-cadherin (Fig. 7b, c). These results suggested that the $\beta$-catenin signaling pathway was involved in the anti-proliferative effect of $\beta$-elemene and mediated the regulation of E-cadherin, GFAP, Notch1 and vimentin expression.

\section{$\beta$-Elemene suppressed tumor development in nude mice transplanted with glioblastoma cells}

To evaluate the effect of $\beta$-elemene on glioblastoma in vivo, we subcutaneously injected G1, G2 or U87 cells into the flank of nude mice and then intraperitoneally injected $\mathrm{NaCl}$ or $50 \mathrm{mg} / \mathrm{kg} \beta$-elemene for 1 week. A total of 8 of the 30 nude mice died during days 13-20 owing to reciprocal biting. We observed a significant reduction in the tumor volume in the $\beta$-elemene-treated group compared with the $\mathrm{NaCl}$-treated group from day 9 after 


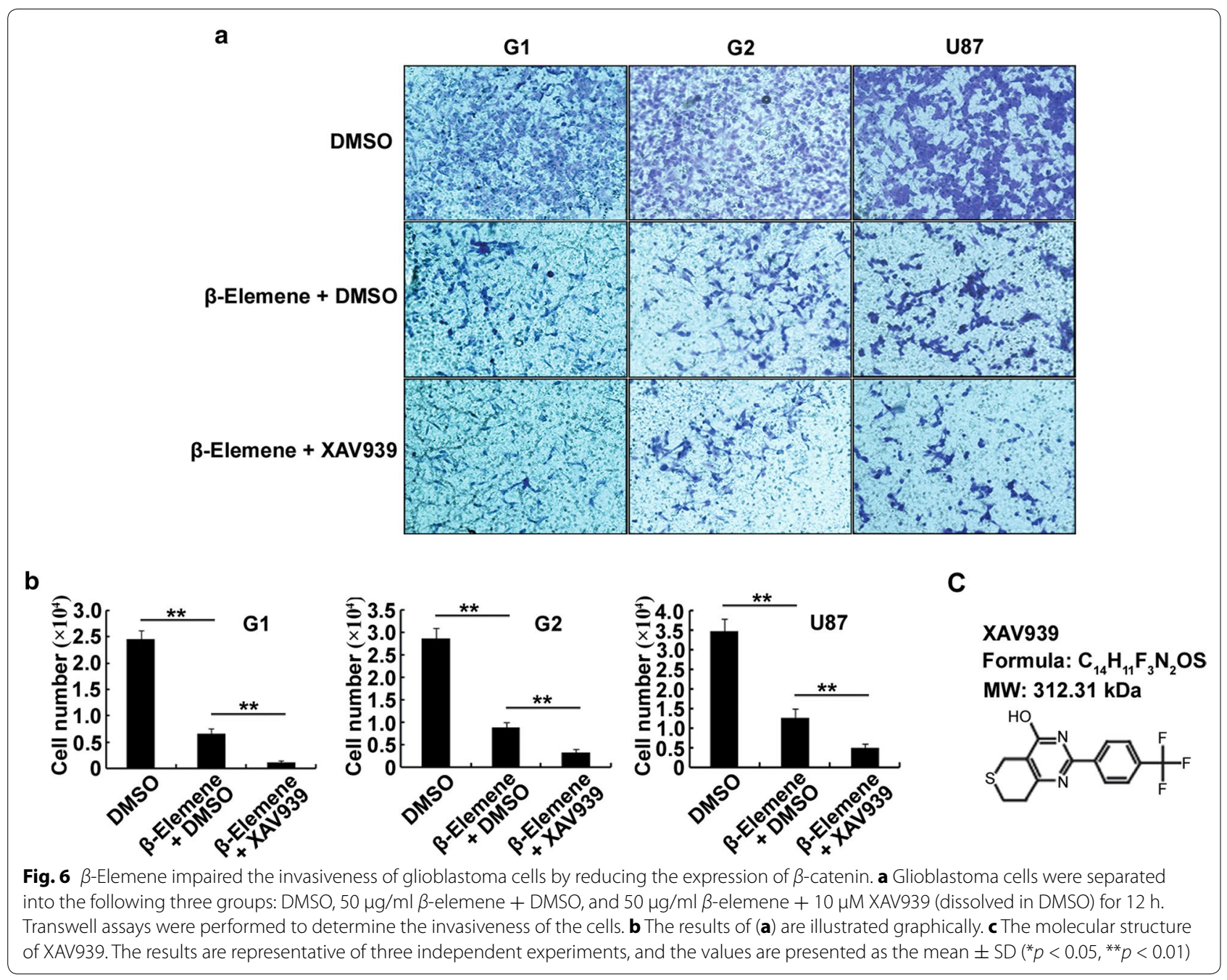

transplantation (day 3 after intraperitoneal injection) to day 21 (Fig. 8a). The tumors were resected and measured on day 21 . The tumor weights of the $\beta$-elemene-treated group were significantly less than those of the $\mathrm{NaCl}-$ treated group (Fig. 8b, c). These results suggested that tumor development was suppressed by $\beta$-elemene in tumor-bearing nude mice.

\section{$\beta$-Elemene regulation of the expression of various stemness-, differentiation- and EMT-related effectors in tumor xenografts in nude mice}

To evaluate the effect of $\beta$-elemene on the expression of stemness-, differentiation- and EMT-related effectors in vivo, we evaluated the expression of CD133, ABCG2, GFAP, Notch1, SHH, vimentin, E-cadherin, N-cadherin and $\beta$-catenin in the aforementioned tumor tissues from glioblastoma cell-transplanted nude mice in the $\beta$-elemene- and $\mathrm{NaCl}$-treated groups by Western blot. We found that the expression levels of CD133, ABCG2,
$\mathrm{N}$-cadherin and $\beta$-catenin were significantly lower in the $\beta$-elemene-treated group than those in the $\mathrm{NaCl}$-treated group and that the expression levels of E-cadherin, GFAP, Notch1 and SHH were higher in the $\beta$-elemene-treated group than those in the NaCl-treated group of G1, G2 and U87 cell-transplanted mice (Fig. 9). Interestingly, $\beta$-elemene downregulated the expression of vimentin in vivo; this result was opposite that of the in vitro procedure. These results suggested that $\beta$-elemene regulates the expression of various stemness-, differentiation- and EMT-related effectors in vivo.

\section{Discussion}

GSCs are considered to be an origin of tumor development, recurrence and drug resistance [30]. The radioresistance and chemoresistance of TSCs markedly decreased after their differentiation into non-stem tumor cells that express characteristic differentiation markers $[31,32]$. In this study, we found that $\mathrm{CD} 133^{+}$and 


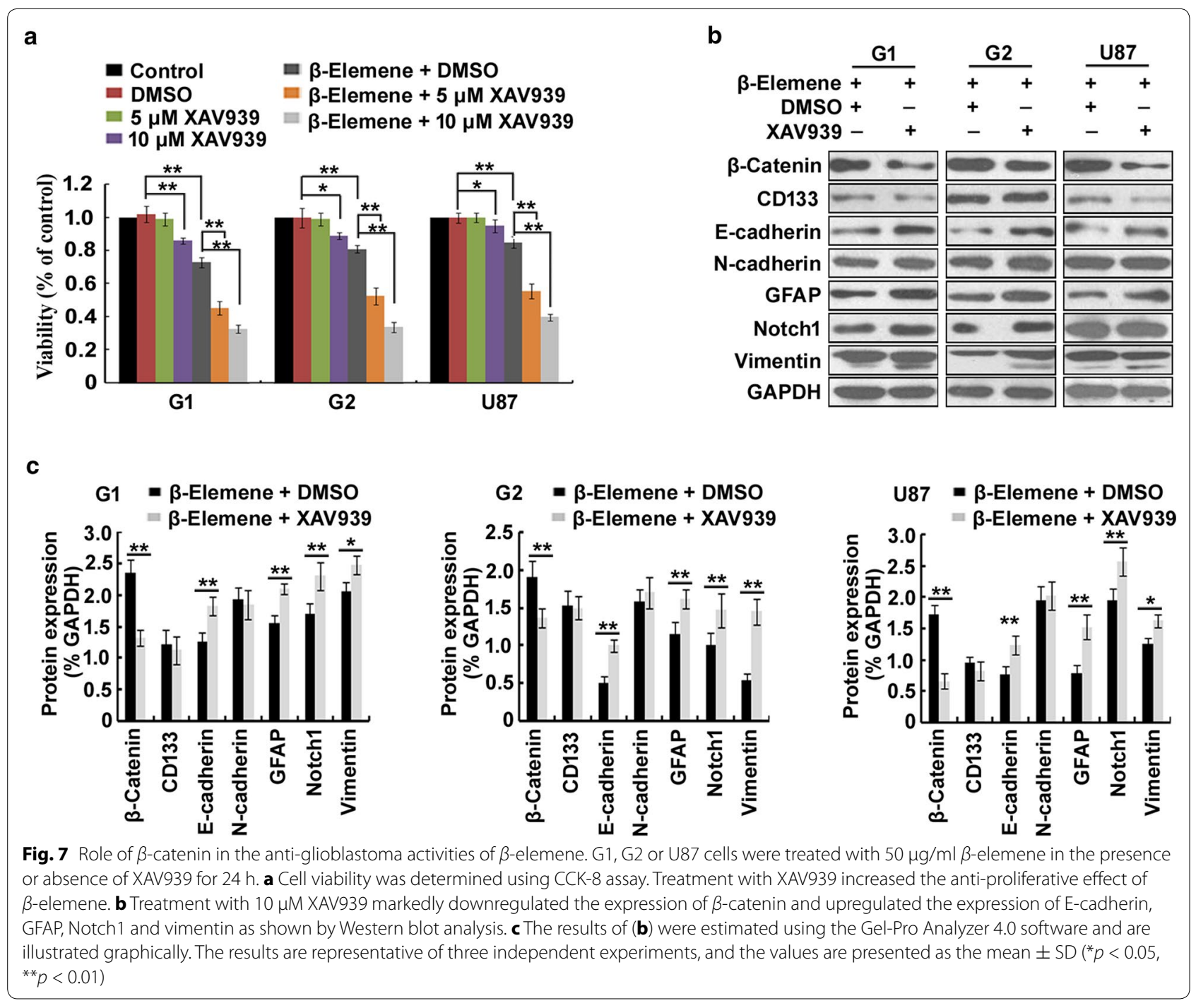

$\mathrm{ABCG}^{+}$cells were sparsely distributed throughout both the G1 and G2 glioblastoma tissues. $\beta$-Elemene treatment resulted in significantly decreased expression levels of CD133 and ABCG2 and increased levels of the differentiation marker GFAP in vitro and in vivo. These results suggested that $\beta$-elemene showed potential effects in impairing stemness and promoting differentiation in glioblastoma cells.

Notch1 and SHH play important and complex roles in the proliferation and differentiation processes of tumor cells. For instance, during the development of non-small cell lung cancer, Notch2 mediated cell differentiation, whereas Notch1 promoted the initiation and development of lung cancer [33]. Attenuating Notch1 signaling mediated the suppressive effect of enhancer-of-split and hairy-related protein 1 on EMT and metastasis in endometrial cancer [34]. However, upregulating the expression of Notch1 may inhibit proliferation and induce differentiation in many tumors. For example, the expression levels of Notch1 and GFAP were high in low-grade glioma and differentiated glioma cells but were low in high-grade glioblastoma cells and GSC spheres. Notch1 and GFAP were considered to be markers of differentiated glioma cells [21]. cAMP promotes the differentiation of rat $\mathrm{C} 6$ glioma cells by activating Notch1 expression [35]. Additionally, Notch1 activation also induced cellular differentiation in anaplastic thyroid cancer [36]. The inactivation of the SHH/GLI1 pathway mediated the anti-glioma effects of curcumin [37]. However, upregulating SHH expression may drive TSCs into the cell cycle and increase the susceptibility of tumor cells to chemoradiotherapy. The activation of the SHH pathway was involved in the diosgenin-induced differentiation of human erythroleukemia cells and mediated the differentiation of mesenchymal 

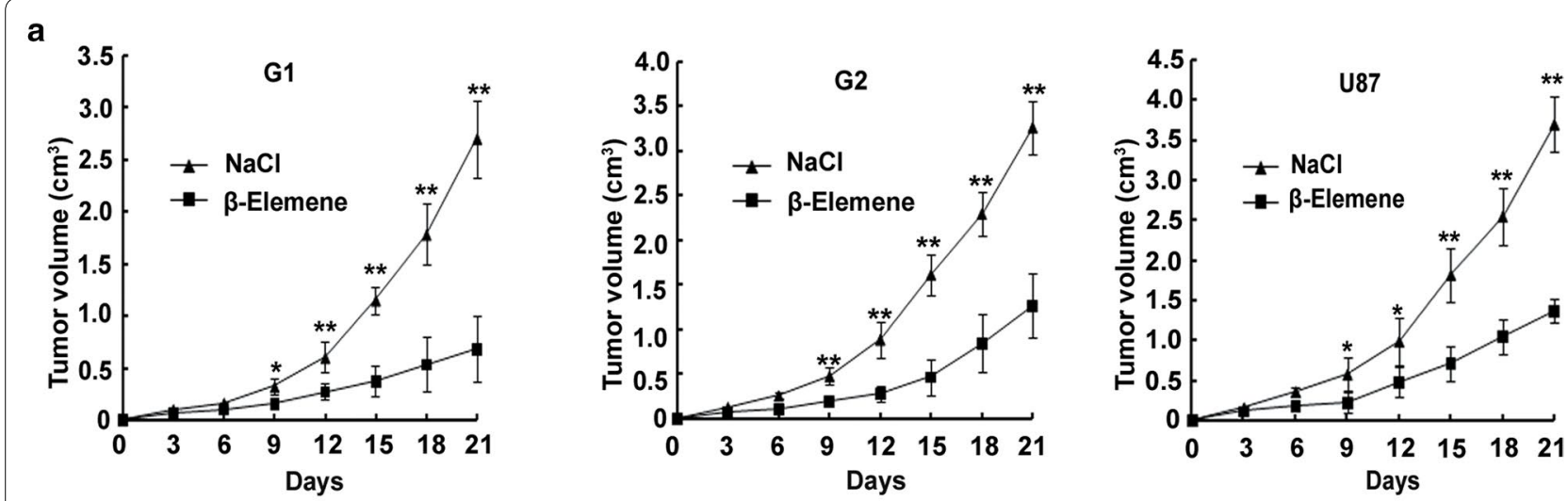

b
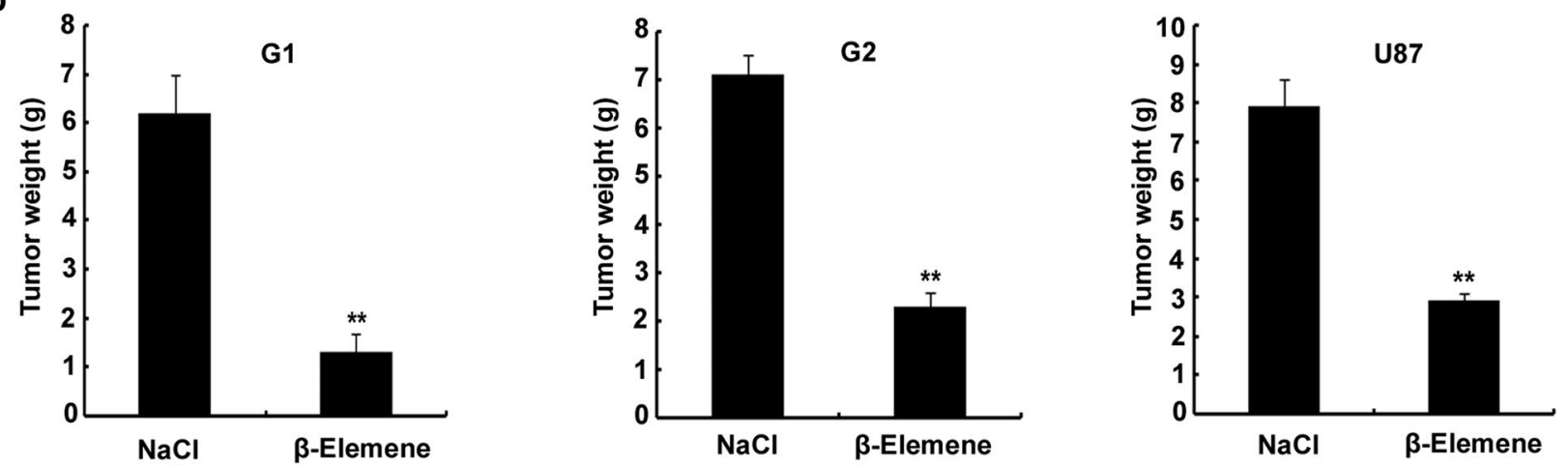

C

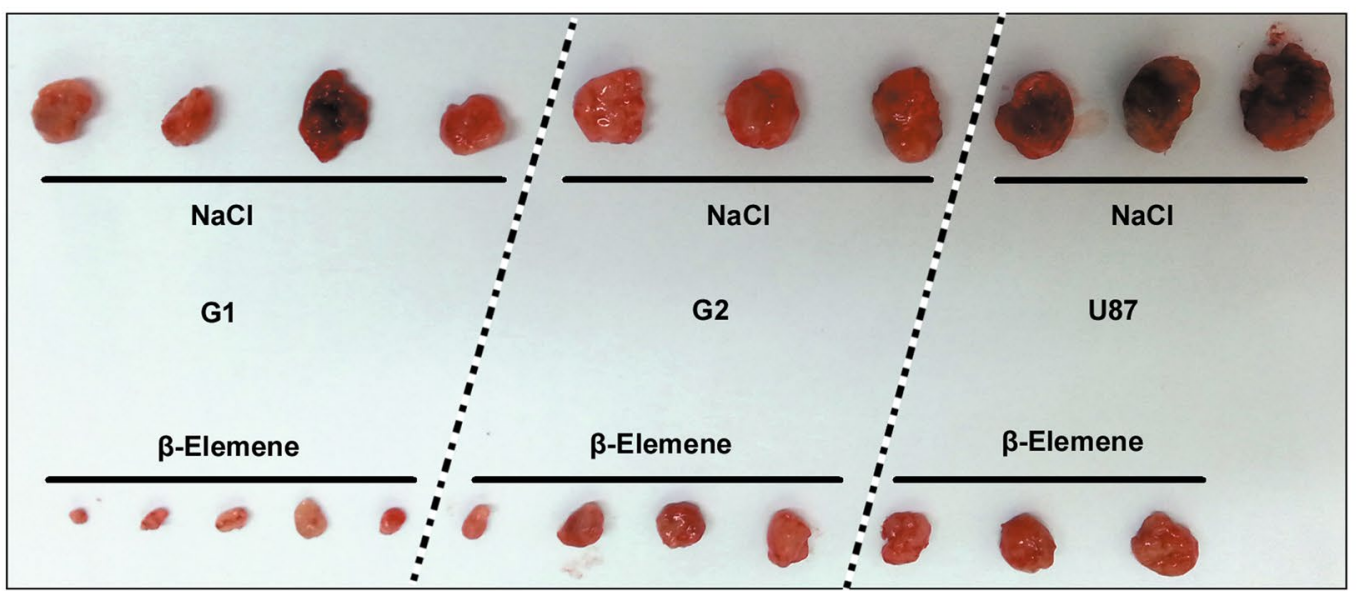

Fig. 8 Tumor development was suppressed by $\beta$-elemene in nude mice transplanted with glioblastoma cells. Nude mice transplanted with glioblastoma cells received an intraperitoneal injection of $\mathrm{NaCl}$ or $50 \mathrm{mg} / \mathrm{kg} \beta$-elemene for 1 week, and the tumor volumes were measured every 3 days. a In contrast with the $\mathrm{NaCl}$-treated group, a remarkable suppression of tumor growth was detected from day 9 after transplantation (day 3 after intraperitoneal injection) to day 21 in the $\beta$-elemene-treated group of G1, G2 or U87 cell-transplanted nude mice. b, c The tumor weights in the $\beta$-elemene group on day 21 after transplantation were significantly less than those of the $\mathrm{NaCl}$ group. The values are presented as the mean $\pm \mathrm{SD}\left({ }^{*} p<0.05,{ }^{* *} p<0.01\right)$

stem cells into neuron-like cells [22, 23]. In this study, we found that the expression levels of Notch1 and SHH were increased by $\beta$-elemene in vitro and in vivo. Upregulating the expression levels of Notch1 and SHH likely contributed to the effect exerted by $\beta$-elemene on glioblastoma cell differentiation. 

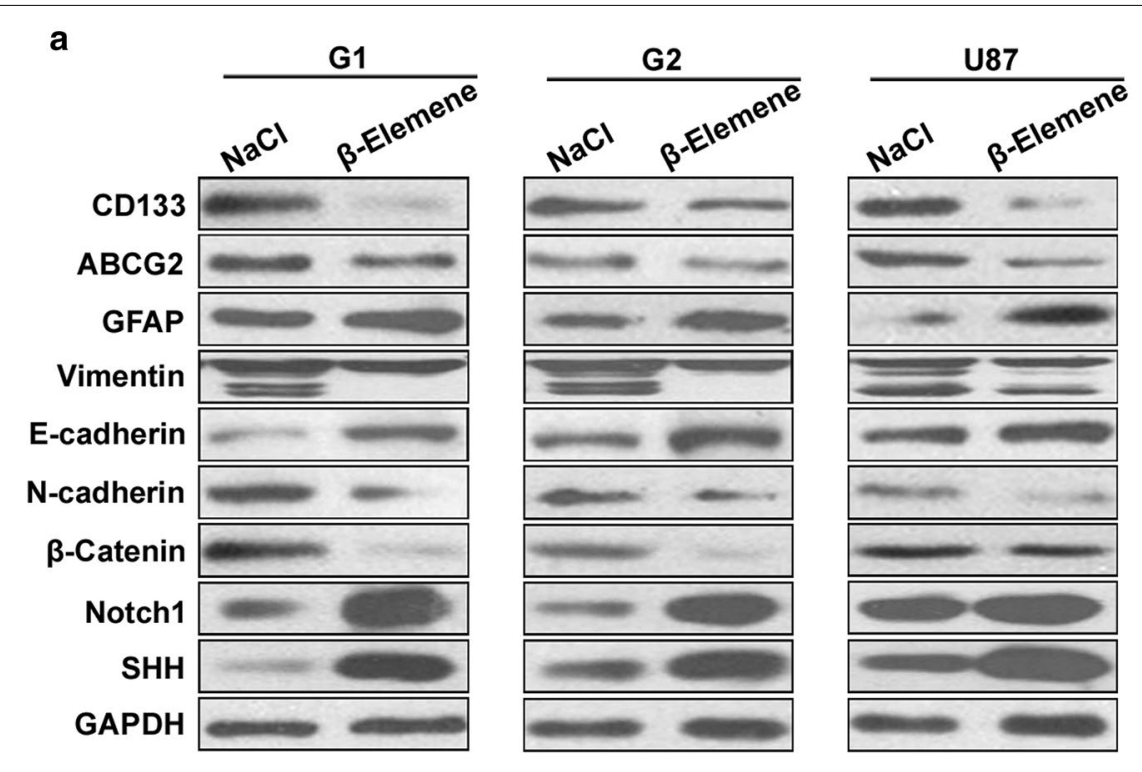

b
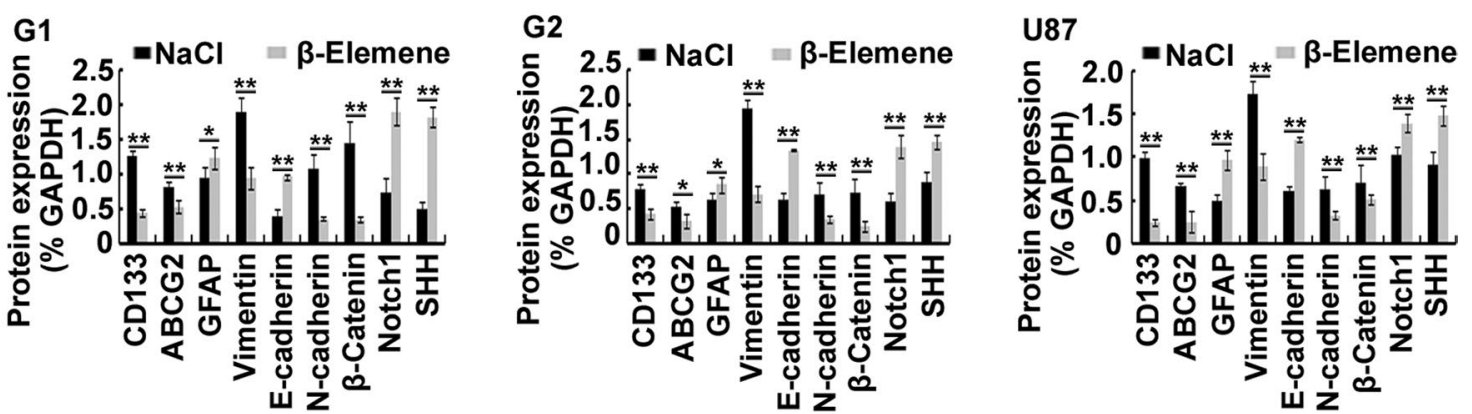

Fig. $9 \beta$-Elemene regulation of stemness-, differentiation- and EMT-related effectors in vivo. a Western blot assays were performed on the aforementioned glioblastoma xenografts in the $\beta$-elemene- and $\mathrm{NaCl}$-treated groups. Expression levels of CD133, ABCG2, $\mathrm{N}$-cadherin and $\beta$-catenin were significantly downregulated and expression levels of E-cadherin, GFAP, Notch1 and SHH were upregulated by $\beta$-elemene. Interestingly, the expression level of vimentin in the $\beta$-elemene-treated group was significantly lower than that in the $\mathrm{NaCl}$-treated group; this result was opposite that for the in vitro procedure. $\mathbf{b}$ The results are representative of three independent experiments, and the values are presented as the mean \pm SD $\left({ }^{*} p<0.05,{ }^{* *} p<0.01\right)$

EMT is a complex molecular and cellular program in which epithelial cells lose their differentiated characteristics, including apical-basal polarity, cell-cell adhesion, and a lack of cell motility, and gain mesenchymal properties, such as motility, invasiveness and increased resistance to apoptosis [38]. The expression of epithelial markers (such as E-cadherin) decreases and the expression of mesenchymal markers (such as vimentin and $\mathrm{N}$-cadherin) increases during EMT $[24,25]$. The Wnt $/ \beta$ catenin pathway also plays a crucial role in the EMT in tumor cells. In this study, we found that $\beta$-elemene reduced the invasiveness of glioblastoma cells in vitro and further showed that $\beta$-elemene inhibited EMT by upregulating the expression levels of E-cadherin and downregulating the expression levels of $\mathrm{N}$-cadherin and $\beta$-catenin in glioblastoma cells in vivo and in vitro.
Interestingly, the expression level of the mesenchymal marker vimentin was increased in vitro by $\beta$-elemene; this result was opposite as observed in vivo. We propose the following four reasons to explain this contradictory phenomenon. (1) The in vitro culture conditions cannot accurately simulate the tumor microenvironment. (2) The changes in cell morphology in vitro in response to drug treatment, including cell-cell dissociation, cell protuberance retraction, rounded morphology, and even detachment from the culture dish surface, are distinct from the morphologic changes in vivo. The expression of vimentin, an intermediate filament protein, is closely associated with alterations in cell morphology, which may partially explain the contradictory expression of vimentin in vitro and in vivo. (3) A previous study showed that increased expression of vimentin 
was involved in the apoptosis of Jurkat leukemia cells [39]. Thus the expression of vimentin may be affected by apoptosis in vitro. (4) A previous study showed that the number of vimentin-positive cells increased during the differentiation process of GSC spheres [40]. Therefore, cell differentiation may be typically accompanied by increased vimentin expression. The precise reason underlying the opposite effects of $\beta$-elemene on vimentin expression in vitro and in vivo must be validated in the future.

$\beta$-Catenin, a member of a protein complex that connects cadherin to the actin cytoskeleton at adherens junctions [41], plays a crucial role in tumor cell proliferation and EMT initiation and progression. Activation of the $\beta$-catenin/Wnt signaling cascade during EMT was associated with suppression of E-cadherin expression [42], and suppressing the $\beta$-catenin pathway inhibited proliferation, induced terminal differentiation and increased the expression of GFAP in glioma cells [43]. A complex crosstalk exists between the $\beta$-catenin pathway and various differentiation- and EMT-related effectors. Activation of $\beta$-catenin signaling at the cerebellar ventricular zone led to a reduction in the number of cells expressing the glial lineage markers Sox9 and GFAP [44]. Activating the Notch1 signaling pathway, which depends on GSK $3 \beta / \beta$-catenin, inhibited cell proliferation and induced apoptosis in the human esophageal squamous cell carcinoma cell line EC9706 [45]. $\beta$-Catenin interacts with the intracytoplasmic region of E-cadherin to maintain cell-cell adhesion. E-cadherin and vimentin are regulated by $\beta$-catenin during EMT in gastric cancer $[46,47]$. In this study, we found that inhibiting $\beta$-catenin using XAV939 enhanced the anti-proliferative and EMT inhibitory effects of $\beta$-elemene on glioblastoma cells and promoted the regulatory effect of $\beta$-elemene on EMT- and differentiation-related molecules. Our findings show that the $\beta$-catenin pathway plays a crucial role in the anti-glioblastoma effects of $\beta$-elemene. Further clarification of the regulatory mechanisms and actions of $\beta$-catenin signaling in anti-glioblastoma activities of $\beta$-elemene are required and should be pursued in future studies.

\section{Conclusions}

$\beta$-Elemene clearly inhibited cell proliferation, induced cell apoptosis, promoted cell differentiation and reversed EMT by regulating the expression of a series of stemness-, differentiation- and EMT-related molecules in glioblastoma cells in vitro and in vivo. The $\beta$-catenin pathway played a crucial role in the anti-tumor action of $\beta$-elemene. This study provides promising evidence supporting $\beta$-elemene as a valuable future agent for glioblastoma therapy.

\section{Abbreviations}

EMT: epithelial-to-mesenchymal transition; GSC: glioblastoma stem cell; ABCG2: ATP-binding cassette subfamily G member 2; NSC: neural stem cell; TSC: tumor stem cell; GFAP: glial fibrillary acidic protein; SHH: sonic hedgehog; CCK-8: cell counting kit-8; PI: propidium iodide; MRI: magnetic resonance imaging; DMEM: Dulbecco's modified eagle's medium; SD: standard deviation.

\section{Authors' contributions}

TZ and GL conceived the study. TZ, GL and XL drafted/revised the manuscript and participated in the study design, analysis and interpretation of data. $\mathrm{LL}$ carried out CCK-8 assays. XW and ZL carried out Western blot analysis and primary cell culture. PX and JS performed immunohistochemistry and flow cytometry. Cell invasion assays and animal experiments were carried out by XG and ZS. Statistical analysis was performed by TZ and ZS. All authors read and approved the final manuscript.

\section{Author details \\ ${ }^{1}$ Department of Neurosurgery, General Hospital of Shenyang Military Area Command, No. 83, Wenhua Road, Shenhe District, Shenyang 110840, China. ${ }^{2}$ Health Care Centre, Shenyang Entry-Exit Inspection and Quarantine Bureau, Shenyang, China.}

\section{Acknowledgements}

This research was supported by the Post-doctoral Science Foundation of China (No. 2012M521921), the Liaoning Province Science and Technology Key Projects (No. 2013225089) and Liaoning Province Natural Science Foundation (No. 2015020422). The funders had no role in study design, data collection and analysis, decision to publish, or preparation of the manuscript.

\section{Competing interests}

The authors declare that they have no competing interests.

Received: 18 December 2014 Accepted: 5 November 2015 Published online: 12 November 2015

\section{References}

1. Van Meir EG, Hadjipanayis CG, Norden AD, Shu HK, Wen PY, Olson J. Exciting new advances in neuro-oncology: the avenue to a cure for malignant glioma. CA Cancer J Clin. 2010;60:166-93.

2. Omuro A, DeAngelis LM. Glioblastoma and other malignant gliomas: a clinical review. JAMA. 2013;310:1842-50.

3. Shah U, Morrison T. A review of the symptomatic management of malignant gliomas in adults. J Natl Compr Canc Netw. 2013;11:424-9.

4. Eyüpoglu IY, Buchfelder M, Savaskan NE. Surgical resection of malignant gliomas-role in optimizing patient outcome. Nat Rev Neurol. 2013;9:141-51.

5. Chen SL, You J, Wang GJ. Supercritical fluid extraction of $\beta$-elemene under lower pressure. Se Pu. 2001;19:179-81 (in Chinese).

6. Zhang $X$, Zhang Y, LiY. $\beta$-elemene decreases cell invasion by upregulating E-cadherin expression in MCF-7 human breast cancer cells. Oncol Rep. 2013;30:745-50.

7. Zhu T, Zhao Y, Zhang J, Li L, Zou L, Yao Y, et al. $\beta$-Elemene inhibits proliferation of human glioblastoma cells and causes cell-cycle g0/g1 arrest via mutually compensatory activation of MKK3 and MKK6. Int J Oncol. 2011;38:419-26

8. Yao YQ, Ding $X$, Jia YC, Huang $C X$, Wang $Y Z$, Xu YH. Anti-tumor effect of beta-elemene in glioblastoma cells depends on p38 MAPK activation. Cancer Lett. 2008;264:127-34.

9. Zhu T, Xu Y, Dong B, Zhang J, Wei Z, Xu Y, et al. $\beta$-Elemene inhibits proliferation of human glioblastoma cells through the activation of gliamaturation factor $\beta$ and induces sensitization to cisplatin. Oncol Rep. 2011;26:405-13.

10. Zhao YS, Zhu TZ, Yao YQ, Wu CM, Wei ZQ, Wang W, et al. $\beta$-Elemene inhibits Hsp90/Raf-1 molecular complex inducing apoptosis of glioblastoma cells. J Neuro-oncol. 2012;107:307-14.

11. Zhu TZ, Li XM, Luo LH, Song ZQ, Gao X, Li ZQ, et al. $\beta$-Elemene inhibits stemness promotes differentiation and impairs chemoresistance to temozolomide in glioblastoma stem-like cells. Int J Oncol. 2014;45:699-709. 
12. Lathia JD, Mack SC, Mulkearns-Hubert EE, Valentim CL, Rich JN. Cancer stem cells in glioblastoma. Genes Dev. 2015;29:1203-17.

13. Choy W, Nagasawa DT, Trang A, Thill K, Spasic M, Yang I. CD133 as a marker for regulation and potential for targeted therapies in glioblastoma multiforme. Neurosurg Clin N Am. 2012;23:391-405.

14. Zhang B, Sun J, Yu SP, Chen C, Liu B, Liu ZF, et al. Rac1 ${ }^{+}$cells distributed in accordance with $\mathrm{CD}_{133^{+}}$cells in glioblastomas and the elevated invasiveness of $\mathrm{CD}_{133^{+}}$glioma cells with higher Rac1 activity. Chin Med J (Engl). 2012;125:4344-8.

15. Singh SK, Clarke ID, Terasaki M, Bonn VE, Hawkins C, Squire J, et al. Identification of a cancer stem cell in human brain tumors. Cancer Res. 2003;63:5821-8.

16. Ding XW, Wu JH, Jiang CP. ABCG2: a potential marker of stem cells and novel target in stem cell and cancer therapy. Life Sci. 2010;86:631-7.

17. Dean M, Fojo T, Bates S. Tumour stem cells and drug resistance. Nat Rev Cancer. 2005;5:275-84.

18. Bleau AM, Huse JT, Holland EC. The ABCG2 resistance network of glioblastoma. Cell Cycle. 2009;8:2936-44.

19. Scharenberg CW, Harkey MA, Torok-Storb B. The ABCG2 transporter is an efficient Hoechst 33342 efflux pump and is preferentially expressed by immature human hematopoietic progenitors. Blood. 2002;99:507-12.

20. Nakanishi T, Ross DD. Breast cancer resistance protein (BCRP/ABCG2): its role in multidrug resistance and regulation of its gene expression. Chin J Cancer. 2012:31:73-99.

21. Dell'albani P, Rodolico M, Pellitteri R, Tricarichi E, Torrisi SA, D'Antoni S, et al. Differential patterns of NOTCH1-4 receptor expression are markers of glioma cell differentiation. Neuro Oncol. 2014;16:204-16.

22. Ghezali L, Liagre B, Limami Y, Beneytout JL, Leger DY. Sonic Hedgehog activation is implicated in diosgenin-induced megakaryocytic differentiation of human erythroleukemia cells. PLoS One. 2014;9:e95016.

23. Huang JG, Shen CB, Wu WB, Ren JW, Xu L, Liu S, et al. Primary cilia mediate sonic hedgehog signaling to regulate neuronal-like differentiation of bone mesenchymal stem cells for resveratrol induction in vitro. J Neurosci Res. 2014;92:587-96.

24. Adhikary A, Chakraborty S, Mazumdar M, Ghosh S, Mukherjee S, Manna A, et al. Inhibition of Epithelial to Mesenchymal transition by E-cadherin up-regulation via repression of Slug transcription and inhibition of E-cadherin degradation: dual role of SMAR1 in breast cancer cells. J Biol Chem. 2014;289:25431-44.

25. Bronsert P, Enderle-Ammour K, Bader M, Timme S, Kuehs M, Csanadi $A$, et al. Cancer cell invasion and EMT marker expression-a threedimensional study of the human cancer-host interface. J Pathol. 2014;234:410-22.

26. Zhang K, Zhu S, Liu Y, Dong X, Shi Z, Zhang A, et al. ICAT inhibits glioblastoma cell proliferation by suppressing Wnt/ $\beta$-catenin activity. Cancer Lett. 2015;357:404-11.

27. Chen X, Hu W, Xie B, Gao H, Xu C, Chen J. Downregulation of SCAI enhances glioma cell invasion and stem cell like phenotype by activating Wnt/ $\beta$-catenin signaling. Biochem Biophys Res Commun. 2014;448:206-11.

28. Chen HL, Chew LJ, Packer RJ, Gallo V. Modulation of the Wnt/beta-catenin pathway in human oligodendroglioma cells by Sox 17 regulates proliferation and differentiation. Cancer Lett. 2013;335:361-71.

29. Wang Y, Zeng S, Lin TM, Krugner-Higby L, Lyman D, Steffen D, et al. Evaluating the Anticancer Properties of Liposomal Copper in a Nude Xenograft Mouse Model of Human Prostate Cancer: formulation, In vitro, In vivo, Histology and Tissue Distribution Studies. Pharm Res. 2014;31:3106-19.

30. Mantwill K, Naumann U, Seznec J, Girbinger V, Lage H, Surowiak P, et al. YB-1 dependent oncolytic adenovirus efficiently inhibits tumor growth of glioma cancer stem like cells. J Transl Med. 2013;11:216.

31. Beier D, Schulz JB, Beier CP. Chemoresistance of glioblastoma cancer stem cells-much more complex than expected. Mol Cancer. 2011;10:128.
32. Liu G, Yuan X, Zeng Z, Tunici P, Ng H, Abdulkadir IR, et al. Analysis of gene expression and chemoresistance of $\mathrm{CD}_{133^{+}}$cancer stem cells in glioblastoma. Mol Cancer. 2006;5:67.

33. Baumgart A, Mazur PK, Anton M, Rudelius M, Schwamborn K, Feuchtinger A, et al. Opposing role of Notch1 and Notch2 in a KrasG12D-driven murine non-small cell lung cancer model. Oncogene. 2015;34:578-88.

34. Liao Y, He X, Qiu H, Che Q, Wang F, Lu W, et al. Suppression of the epithelial-mesenchymal transition by SHARP1 is linked to the Notch1 signaling pathway inmetastasis of endometrial cancer. BMC Cancer. 2014;14:487.

35. Angulo-Rojo C, Manning-Cela R, Aguirre A, Ortega A, López-Bayghen E. Involvement of the Notch pathway in terminal astrocytic differentiation: role of PKA. ASN Neuro. 2013;5:e00130.

36. Patel PN, Yu XM, Jaskula-Sztul R, Chen $\mathrm{H}$. Hesperetin activates the notch signaling cascade, causes apoptosis, and induces cellular differentiation in anaplastic thyroid cancer. Ann Surg Oncol. 2014;21:497-504.

37. Du WZ, Feng Y, Wang XF, Piao XY, Cui YQ, Chen LC, et al. Curcumin suppresses malignant glioma cells growth and induces apoptosis by inhibition of SHH/GLI1 signaling pathway in vitro and vivo. CNS Neurosci Ther 2013;19:926-36.

38. Mao Y, Xu J, Li Z, Zhang N, Yin H, Liu Z. The role of nuclear $\beta$-catenin accumulation in the Twist2-induced ovarian cancer EMT. PLoS One. 2013:8:e78200.

39. Hsu PC, Liao YF, Lin CL, Lin WH, Liu GY, Hung HC. Vimentin is involved in peptidylarginine deiminase 2-induced apoptosis of activated Jurkat cells. Mol Cells. 2014;37:426-34

40. Wu TF, Chen JM, Chen SS, Chen GL, Wei YX, Xie XS, et al. Phenotype of SHG-44 glioma stem cell spheres and pathological characteristics of their xenograft tumors. Zhonghua Zhong Liu Za Zhi. 2013;35:726-31 (in Chinese).

41. Maguschak KA, Ressler KJ. The dynamic role of beta-catenin in synaptic plasticity. Neuropharmacology. 2012;62:78-88.

42. Fransvea E, Angelotti U, Antonaci S, Giannelli G. Blocking transforming growth factor-beta up-regulates E-cadherin and reduces migration and invasion of hepatocellular carcinoma cells. Hepatology. 2008;47:1557-66.

43. Wang Y, Zhang Y, Qian C, Cai M, Li Y, Li Z, et al. GSK3 $\beta / \beta$-catenin signaling is correlated with the differentiation of glioma cells induced by wogonin. Toxicol Lett. 2013;222:212-23.

44. Selvadurai HJ, Mason JO. Activation of Wnt/ $\beta$-catenin signalling affects differentiation of cells arising from the cerebellar ventricular zone. PLOS One. 2012;7:e42572.

45. Lu Z, Liu H, Xue L, Xu P, Gong T, Hou G. An activated Notch1 signaling pathway inhibits cell proliferation and induces apoptosis in human esophageal squamous cell carcinoma cell line EC9706. Int J Oncol. 2008;32:643-51.

46. Zhao L, Li W, Zang W, Liu Z, Xu X, Yu H, et al. JMJD2B promotes epithelialmesenchymal transition by cooperating with $\beta$-catenin and enhances gastric cancer metastasis. Clin Cancer Res. 2013;19:6419-29.

47. D'Arcy P, Maruwge W, Wolahan B, Ma L, Brodin B. Oncogenic functions of the cancer-testis antigen SSX on the proliferation, survival, and signaling pathways of cancer cells. PLoS One. 2014;9:e95136.

\section{Submit your next manuscript to BioMed Central and take full advantage of:}

- Convenient online submission

- Thorough peer review

- No space constraints or color figure charges

- Immediate publication on acceptance

- Inclusion in PubMed, CAS, Scopus and Google Scholar

- Research which is freely available for redistribution

Submit your manuscript at

www.biomedcentral.com/submit
C Biomed Central 